\title{
Involvement of Parents in School Related Activities
}

\author{
Rajni Dhingra*, Sarika Manhas and Neetu Sethi \\ P. G. Department of Home Science (Human Development), University of Jammu, \\ Jammu 180 006, Jammu and Kashmir, India \\ Telephone: 0191-2457137, *Mobile: 094191-04644, Fax: 0191-2457137 \\ *E-mail:rajni.dhingra@rediffmail.com
}

KEYWORDS Parental involvement; home-school relationship; parent-teacher interaction

\begin{abstract}
The present paper examined the participation of parents in school related activities. It further aimed to list various means of communication used by parents to get information about their child's school performance and to suggest intervention strategies for improvement of parent school relationship. The sample for the study comprised of 1000 parents of school going children (Classes I-V) selected by random sampling technique (lottery method) from Jammu City. The major tool used for gathering information from the parents was Questionnaire. The areas under concern were: Parent's perception about importance of home school relationship, role envisioned by the parents for their ownselves, sources of information about child's school activities and major issues of discussion with class teacher. It was found that parental involvement in schools was limited. Very few of them were members of governing committee or acted as resource persons. Whenever there was incidence of involvement fathers exceeded in numbers. Parents were mostly concerned about the academic performance of their wards. Majority of mothers visited schools on a regular basis to know about their child's performance. The issues of discussion were mainly conduct of the child and general school performance. However, parents used varied sources to gather information about child related issues and the most commonly used medium was school dairy (71\%) followed by parent teacher meeting (50\%), school magazine etc.
\end{abstract}

\section{INTRODUCTION}

Parental involvement in education has long been topic of interest among those concerned with optimal development. With increasing frequency, issues related to parental involvement have also been examined with reference to educational outcomes during adolescence. Across a range of studies, there has emerged a strong conclusion that parental involvement in child education generally benefits children's learning and school success (Chavkin and Williams, 1993; Eccles and Harold, 1993; Epstein, 1994; US Department of Education, 1994). Recent work describing the correlates and forms of parental involvement, as well as teachers and school influences on involvement, has long been an important part of the current effort to understand why parents choose to become involved and why their involvement often functions to create positive outcomes for their children of all ages (Eccles and Harold, 1994; Hoover-Dempsey and Sandler, 1996).

Parental involvement may occur at different levels, ranging from simplistic tasks such as motivating children, being positive about school, or assisting children with their homework to more complicated and skill demanding tasks such as assisting educators or the official management of schools, which demands higher skill levels (Khan, 1996). Participation in activities such as fund raising, assisting educators with academic or extramural activities and motivating children to perform well in the school depends on the extent to which the school and the principal encourage such involvements. The participation of parents indeed has a positive influence on the academic achievement of their children (Gene and Stoneman, 1995). There have been many well documented initiatives in parental involvement (Culling, 1985; Topping and Wolfendale, 1985; Atkin et. al., 1988; Macleod, 1989; Wolfendale, $1989,1992)$ which collectively provide testimony to the effectiveness of collaborative efforts of the schools and parents for better development of children. Parental involvement in schools has advantage not only for children's development, it also has a reciprocal effect on parents own learning and personality. Edwards and Redfern (1988) reported that parental involvement in reading not only has a positive influence on the children but also the parent's knowledge base is enhanced. Keynes (1981) showed how children felt confident about going to school in light of their parent's involvement at school. Parents tended to see themselves as having an integral role, together with the school, in educating children. As they construed it, their parental roles 
involved active monitoring or "keeping on top of" children's progress, they also saw themselves as responsible for intervening in school decisions (Lareau, 1987, 1989).

\section{Parent's Decision to Become Involved in their Child's Education}

When applied to parents' choices about involvement in children's education, the decision is often influenced by parent's construction of the parents role, general role construction and parents' beliefs about child development and child rearing (Hoover-Dempsey and Sandler, 1996). Work pertinent to understanding parent's role constructions has been drawn largely from theory in social psychology that explains the emergence of role concepts on human behavior. In keeping with the literature, it is evident that parents' beliefs about child development exert influence on the parenting role they and those significant to them envision for themselves. Another important area, which influence parents' decision is, parent's sense of efficacy for helping the child succeeds in school. Eccles and Harold (1993) defined parents' efficacy beliefs as being composed of three variables: parents confidence that they can help their children with school work, parents views of their competence as their children progress to higher grades and parents' beliefs that they can influence school governance. Hoover Dempsey and Sandler (1996) pointed out another area i.e. general invitations, demands and opportunities of parental involvement. Effective general invitation and demands may come both from children and their schools. Children may hold more emotional influence over parental decisions because of their relationship involved.

Some countries have passed resolutions to make parental involvement in school Programmes mandatory. An example in this direction is the specific perspective on the partnership between schools and parents as implicated in the South African Schools (SASA) of 1996 because it states that the relationship of trust between the School Governing Body (SGB) and the school is important for the effective governance of schools. Similarly in British and American system of Education parents and other role players such as teachers play a major function in the management and governance of local schools (Heystek, 2003; Adrian, 1995). Parents tend to get involved only if there is crisis whereas rest of the time, it is hard work of the principals and educators to get parents involved (Khan, 1996; Blasé and Blasé, 1997). Parental involvement can be viewed as a "preventive" approach in that "problems" can be "caught" and dealt with before they exacerbate. The participation of parents in schools has a positive influence on the academic achievement of their children (Gene and Stonemen, 1995; Chopra, 1970). The above discussion thus reveals the positive impact of parental participation on children's school performance and school lives. Researchers all over the world have investigated this phenomenon to draw implications for use in theory and practice. However, study of this kind has not been conducted in the context adopted for present research. Jammu, being a state capital (during winters) is still evolving its system of education to suit the new changing demands of society. The results of the present research can thus help provide inputs towards strengthening these upcoming systems. The present study was conducted in order to assess the level of parental involvement in children's schools. It further aimed to find out the means of communication used by parents and schools for exchange of messages related to school and the child and suggest intervention strategies for improvement of parent child relationship with specific reference to the ecological context.

\section{PROCEDURE}

The study was conducted on a representative sample of 1000 parents (both fathers and mothers) of school going children between class I-V. The entire sample was drawn from Jammu City in the J and K State of India. Multi stage sampling technique was used for the selection of desired sample (Table 1). Majority of schools covered under the course of study were private higher secondary with an exception of one, which was a private high school. 100 students were randomly selected from each school, studying in class I-V, in order to obtain the desired number of sample. Tools used for the study was Questionnaire (self devised) and the major areas under concern wereHome school relationship, Role envisioned by parents for their ownselves, Sources of information about child's school activities, major issues of discussion with class teacher. Both qualitative and quantitative methods of analysis were used. Content analysis was done for qualitative data and various suitable statistical 
methods were employed to analyze the data quantitatively. The statistical methods used weret-test of significance for differences of mean and Pearson's chi-square.

\section{RESULTS AND DISCUSSION}

Results revealed that majority of fathers (31\%) and mothers (40\%) were graduates. Almost similar percentages of parents (19\% fathers and $18 \%$ mothers) were post-graduates. However, more fathers (10\%) as compared to mothers (2\%) were professionally qualified. t- test of difference was applied and revealed no significant difference in the educational level of fathers and mothers. This reveals that the sample parents had similar level

Table 1: Sampling plan: Multi-stage sampling technique was used as shown in the following plan.

JAMMU CITY

56 Schools (a list was obtained from Zonal Education Office)

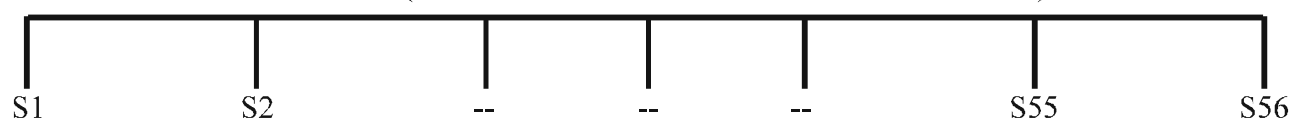

(there were total of 56 schools in Jammu City, 6 schools were excluded
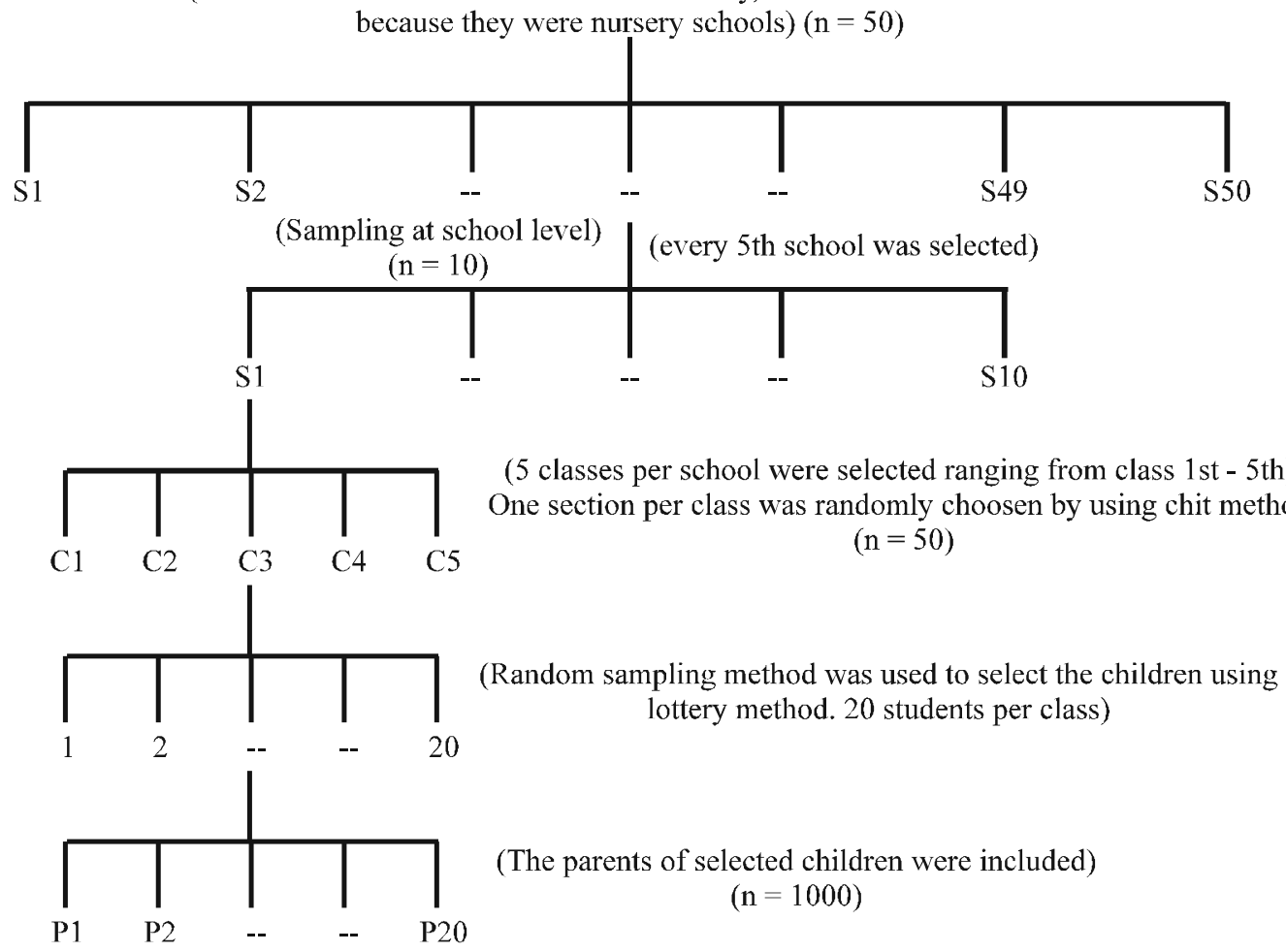

Key

$\mathrm{S}=$ Schools

$\mathrm{C}=$ Classes

$\mathrm{P}=$ Parents 
of education. $34 \%$ of mothers and $29 \%$ fathers were in the age group of 35-39 years followed by a quarter each (25\%) in 30-34 years age group. Mean age of mothers was found to be 35.59 with a standard deviation of 5.26 whereas the mean age of fathers was found to be 38.62 with a standard deviation of 5.24. t- test of difference of means was calculated and revealed that there was a significant difference in the age of mothers and fathers. The mean age of mothers was lower than fathers.

Data revealed that $64 \%$ of female respondents were homemakers only, followed by a large number in teaching profession either in government $(15 \%)$ or private sector $(17 \%)$. Few sample mothers were found in varied professions such as business (2\%), medicine (1\%) and engineering $(1 \%)$. On the other hand, majority of fathers were businessmen (58\%) followed by $14 \%$ who were self-employed. A remarkable segment of respondents were also found engaged in teaching profession either in private schools $(10 \%)$ or in government schools (4\%). The group of respondents varied in terms of their occupation.

\section{Parental Involvement in School Related Areas}

Participation of Parents in School Activities: Data on parent's participation in various school related activities revealed that $7 \%$ of them were members of governing or school committees. Further, the results indicated that most parents were not involved in any specialized committee or administrative activities of the school. $11 \%$ of sample parents were found to be acting as resource person in their children's school. Also a remark-able percentage of parents (18\%) were found to be involved in other school related activities such as arranging field trips, transportation arrangements, providing uniforms etc. (Table 2). No gender differences were found in the involvement of parents in their ward's school.

Frequency of Parent's Visit to School: The results revealed that the mothers visited the schools more frequently than the fathers. Mothers visited the schools either on weekly $(25 \%)$ or monthly $(25 \%)$ basis. However, another $25 \%$ of them visited schools occasionally such as parent teacher meetings, parent's day and similar occasions. On the other hand, only $26 \%$ of fathers paid monthly visits. Majority of them visited schools occasionally $(26 \%)$ or rarely $(25 \%)$ (Table 3). It was reported that since the fathers had to attend offices/ jobs, they normally could not visit the schools. Some fathers even mentioned that since the mothers took care of academics of the children, so they are in a better position to pay visits to the schools. Perhaps, it also exhibits the traditional stereo-typical view that young children's education is the domain responsibility of mothers.

Issues of Discussion with Child's School Teacher: The data in table 4 reveals that more mothers than fathers discussed matters related to academics with the school teacher. However,

Table 2: Participation of parents

\begin{tabular}{|c|c|c|c|c|c|c|}
\hline \multirow[t]{2}{*}{ Participation } & \multicolumn{2}{|c|}{ Mothers $(n=303)$} & \multicolumn{2}{|c|}{ Fathers $(n=697)$} & \multicolumn{2}{|c|}{ Total $(n=1000)$} \\
\hline & $n$ & $\%$ & $n$ & $\%$ & $n$ & $\%$ \\
\hline Member of Governing Body* & 9 & 3 & 58 & 8 & 67 & 7 \\
\hline Member of School Committee* & 20 & 7 & 97 & 14 & 117 & 12 \\
\hline Acting as Resource Person & 30 & 10 & 84 & 12 & 114 & 11 \\
\hline Any other Participation & 47 & 16 & 130 & 19 & 177 & 18 \\
\hline
\end{tabular}

$\chi^{2}$ values $\mathrm{I}=9.74, \mathrm{II}=10.92, \mathrm{III}=0.87, \mathrm{IV}=2.09, \mathrm{df}=3, *$ Significant at $5 \%$.

Table 3: Frequency of parent's visit to schools

\begin{tabular}{|c|c|c|c|c|c|c|}
\hline \multirow[t]{2}{*}{ Frequency } & \multicolumn{2}{|c|}{ Mothers $(n=303)$} & \multicolumn{2}{|c|}{ Fathers $(n=697)$} & \multicolumn{2}{|c|}{ Total $(n=1000)$} \\
\hline & $n$ & $\%$ & $n$ & $\%$ & $n$ & $\%$ \\
\hline Daily & 17 & 6 & 62 & 9 & 79 & 8 \\
\hline Weekly & 76 & 25 & 5 & 1 & 81 & 8 \\
\hline Fortnightly & 22 & 7 & 66 & 9 & 88 & 9 \\
\hline Monthly & 75 & 25 & 183 & 26 & 256 & 26 \\
\hline Occasionally & 78 & 25 & 183 & 26 & 261 & 26 \\
\hline Rarely & 35 & 12 & 173 & 25 & 208 & 20 \\
\hline No response/Never & - & - & 25 & 4 & 25 & 3 \\
\hline
\end{tabular}

$\chi^{2}=357.46^{*}, \mathrm{df}=6$, Tab. Value $=16.8$, Significant at $1 \%$. 
all the parents also discussed the conduct of the child and behavioral aspects in the school. Fathers also reported talking about specific behavioral problems of the child more times than the mothers. Results revealed that the parents discussed about school performance of children $(29 \%)$, specific academic learning (24\%) and conduct of the child in the class (30\%). For most mothers academic and school performance related aspects were more important.

Sources of Information about Child's School Activities: The data presented in table 5 reveals that there were different sources from which the parents obtained information about school related activities of their children. Formal Parent Teacher meetings appeared to be the major source for this purpose. Parent Teacher Meetings were attended frequently by the majority of parents $(50 \%)$. Gender wise classification revealed that more mothers than fathers attended these parent teacher meetings. Mostly the parents enquired about the academic status of their children besides asking about their personality and social interaction.

Majority of the parents did not regularly have informal meetings with the teachers. $36 \%$ of them occasionally went to meet the teacher. This was especially when the children scored low marks than expected by the parents, or when children were unwell or unable to attend school for long or on certain special occasions. Another $38 \%$ met the teachers rarely. Most of them felt that the parent teacher meetings were enough to get to know about the children. It was encouraging to note that $23 \%$ of the parents made it a point to see the teacher informally from time to time. Both mothers and fathers reported meeting the teachers informally.

School dairy was also frequently used by majority of the parents $(71 \%)$ as a means of communication with teachers. More mothers $(79 \%)$ than fathers $(68 \%)$ used this mode of communication. It was a common feature for teachers to write notes in the diaries of the students on a daily basis. These diaries became important tools for teachers as they sent written comments through these to the parents. Most of the parents made it a point to read these diaries, on daily basis and give back their comments.

Figures in the table5 revealed that most of the parents $(63 \%)$ rarely referred to school magazines. It was noted that most of the parents felt that school magazines were good source of information as far as school administration and activities were concerned but they were unable to give direct and individual information about their child. Calling up the teacher on phone was rarely used by the parents to gather information about the children. Only when it was highly important or impossible for the parents to go and personally meet the teacher, they rang her up. Only $10 \%$ of the parents called the teacher on a

Table 4: Issues of discussion with child' class teacher

\begin{tabular}{|c|c|c|c|c|c|c|}
\hline \multirow[t]{2}{*}{ Issues } & \multicolumn{2}{|c|}{ Mothers $(n=303)$} & \multicolumn{2}{|c|}{ Fathers $(n=697)$} & \multicolumn{2}{|c|}{ Total $(n=1000)$} \\
\hline & $n$ & $\%$ & $n$ & $\%$ & $n$ & $\%$ \\
\hline Academics & 100 & 33 & 141 & 20 & 241 & 24 \\
\hline Conduct of the child & 85 & 29 & 216 & 31 & 301 & 30 \\
\hline General schoolPerformance & 104 & 34 & 182 & 26 & 289 & 29 \\
\hline Specific behavior problem & 10 & 3 & 102 & 15 & 112 & 11 \\
\hline Multiple response & 4 & 1 & 50 & 7 & 54 & 5 \\
\hline Undecided & - & - & 6 & 1 & 6 & 1 \\
\hline
\end{tabular}

$\chi^{2}=59.99^{*}, \mathrm{df}=5$, Tab. Value $=15.1^{*}$, Significant at $1 \%$.

Table 5: Sources of information about child's school activities

\begin{tabular}{|c|c|c|c|c|c|c|c|c|c|}
\hline \multirow[t]{2}{*}{ Sources } & \multicolumn{3}{|c|}{ Mothers $(n=303)$} & \multicolumn{3}{|c|}{ Fathers $(n=697)$} & \multicolumn{3}{|c|}{ Total $(n=1000)$} \\
\hline & $F$ & $O$ & $R$ & $F$ & $O$ & $R$ & $F$ & $O$ & $R$ \\
\hline Parent teacher meeting* & $148(49)$ & $141(47)$ & $14(4)$ & $351(50)$ & $209(30)$ & $137(20)$ & $499(50)$ & $350(35)$ & $151(15)$ \\
\hline School diary & 238(79) & $38(13)$ & 27(8) & $473(68)$ & $107(15)$ & $117(17)$ & $711(71)$ & $145(15)$ & $144(14)$ \\
\hline Informal meeting* & $73(24)$ & $108(36)$ & $122(40)$ & $161(23)$ & $279(40)$ & $257(37)$ & $234(23)$ & $387(19)$ & $379(38)$ \\
\hline School Magazines & $29(10)$ & $83(27)$ & 191(63) & $123(18)$ & $138(20)$ & $436(62)$ & $152(15)$ & $221(22)$ & $627(63)$ \\
\hline Phone the teacher & $28(9)$ & $55(18)$ & $220(73)$ & $73(10)$ & $109(16)$ & $515(74)$ & 101(10) & $164(16)$ & $735(74)$ \\
\hline Any other sources & $41(14)$ & $31(10)$ & $231(76)$ & $79(11)$ & $85(12)$ & $533(77)$ & $120(12)$ & $116(12)$ & $764(76)$ \\
\hline
\end{tabular}

Where $\mathrm{F}$ is Frequently, $\mathrm{O}$ is Occasionally, $\mathrm{R}$ is Rarely

$* \chi^{2}$ values $\mathrm{I}=48.826^{*}, \mathrm{II}=13.61 *, \mathrm{III}=1.67, \mathrm{IV}=14.50^{*}, \mathrm{~V}=1.15, \mathrm{VI}=1.53, \mathrm{df}=5$, Figures in bracket indicates percentage. *Significant at $5 \%$. 
regular basis. The other sources/means used to gather information at times included inquiry from children's friends or parent's own friend whose children were also enrolled in the same school. At times they also personally contacted school authorities or principals about their child's conduct or performance.

\section{SUGGESTIONS FOR INTERVENTION}

During the course of study it was observed that sample parents were found to be involved in school related areas only when the need arose or when they were asked to get involved by the school authorities. Not only this, when there was little involvement, it was found restricted to only academic issues, whereas co-curricular activities were often left untouched. Based on the identified areas the following intervention strategies were put forward:

- Promoting parental involvement in school governance through legal measures, if necessary.

- Developing a positive attitude among school authorities about the need and importance of parental involvement.

- There is an urgent need to communicate to parents that their involvement and support makes a great deal of difference in their children's school performance, and that they need not be highly educated or have large amounts of free time for their involvement to be beneficial. It is important to make this point repeatedly.

- Develop parent involvement programs that include a focus on parent involvement in learning activities with children in the home, assisting with homework, and monitoring and encouraging the learning activities of children.

\section{CONCLUSION}

Mothers and fathers play important roles in the development of young children's positive attitudes towards learning and education (Cowan et al., 1993). Children tend to spend many years in school where there are tasks to be accomplished, people to socialize and be socialized by, and competencies to be developed. But without suitable and ample support from the parents, learning would be a difficult task. Researches have shown the importance of relationship between the school and the parents of children as an important aspect of education (Macron, 1993; McAdoo, et. al., 1993). Parental belief systems and attitudes continue to have a significant positive impact on student outcomes throughout the elementary years, middle school and secondary years (Trusty, 1999; Simon, 1999). Like earlier researches (Heystek, 2003; Macleod, 1989) the present study also shows that parental involvement in schools was rather limited. Very few of them were members of governing body or school committee or acted as resource person. On the other hand, more mothers visited schools to gather information about their children. Most parents visited school either monthly or occasionally and mostly enquired either about the conduct or general school performance of their children. Findings of Balli et al. (1998) also show that parents take interest in the activities of children at school and visit school to gather information. The most common sources of child's school activities were parent-teacher meeting, school diaries and informal meetings. Hughes et al. (1994) also found that most parents attend parents meetings to know about their child. It was concluded that there is a need to realize that mothers and fathers play a role of immense importance in the education and schooling of the young children. Parental attitude translates into children's attitude towards school and learning and therefore it is of utmost importance to incorporate this element in all policies and progammes related to education.

\section{REFERENCES}

Adrain, B. 1995. "Minority parents as school governors in Chicago and Britain: Empowerment or not?" Education Review, 47(3): 431-453.

Atkin, J., J. Bastiani and J. Goode. 1988. Listening to parents. London: Croom Helm.

Balli, S.J., Demo, D.H. and Wedman, J.F. 1998. "Family involvement with children's homework: An intervention in the middle grades." Family Relations, 47: $149-157$

Blasé, J. and J. Blasé. 1997. The Fire is Back: Principals Sharing School Governance. Thousand Oaks, CA: Corwin Press

Chavkin, N.F. and D. L. Williams Jr. 1993. "Minority parents and the elementary school: Attitude and Practices", (pp.73-84) in F.N. Chavkin (ed.), Families and Schools in Pluralistic Society. Albany: State University of New York Press.

Chopra, R.K. 1970. "Parental Reference in Relation to Achievement", (p. 23), in A.K. Gupta and S.K. Sharma (eds.), Parental Influences on Adolescents. New Delhi: Ariana Publishing House.

Cowan, C. P., G. A. Hemming and E. L. Shuck. 1993. "The impact of interventions with parents of preschoolers on the children's adaptation to 
kindergarten." Paper presented at the biennial meeting of the society for research in child development. New Orleans.

Culling Ford, C. 1985. Parents, Teachers and Schools. London: Robert Royce.

Edwards, V. and Redfern, A. 1988. At Home in School: Parent Participation in Primary Education. London: Routledge.

Eccles, J. S. and R. D. Harold. 1993. "Parent School involvement during the early adolescent years." Teachers College Record, 94: 568-587.

Eccles,J.S. and R. D. Harold. 1994. "Family involvement in children's and adolescent schooling." Paper presented at the Family School Links Conference, Pennsylvania Street University.

Epstein, J.L.1994. "Perspectives and previews on research and policy for school, family and community partnership". Paper presented at the Family School Links Conference, Pennsylvania Street University.

Forsyth, D.R. 1990. Group Dynamics. Pacific Grove, C.A: Brooke/ Cole.

Gene, H.B., and Stoneman, Z. 1995. "Linking family processes and academic competence among rural African American youth." Journal of Marriage and Family, 57: 567-579.

Heystek, J. 2003. "Parents as governors and partners in schools." Education and Urban Society, 35(3): 328351.

Hoover-Dempsey, K.V. and H.M. Sandler. 1995. "Parenta involvement in children's education. Why does it make a difference?" Teachers College Record, 95: 310-311.

Hoover-Dempsey, K.V. and H.M. Sandler. 1996. "Parental involvement in elementary children's homework: Parameters of reported strategy and practice." Elementary School Journal 95: 435-450.

Hughes, M., F. Wikely and T. Nash.1994. Parents and their Children's Schools. Oxford: Blackwell.

Keynes, S.K. 1981. "Home and school milieu for meeting children's needs", (pp. 18-36), in Sheila. W. (Eds.),
Primary Schools and Special Needs: Policy, Planning and Provision. London: Cassell.

Khan, M.B. 1996. "Parental Involvement in Education: Possibilities and Limitations." The School Coтmunity Journal, 6: 57-68.

Lareau, A. 1987. "Social class differences in family and school relationships: The importance of cultural capital." Sociology of Education, 60: 73-85.

Lareau,A. 1989. Home Advantage: Social Class and Parental Intervention in Elementary Education. New York: Falmer Press.

Macleod, F. (Ed.) 1989. Parents and Schools: The Contemporary Challenge. Lewes: Falmer Press.

Macron, R.A.1993. "Positive relationships between parent- school involvement and public school inner city preschooler's development and academic performance." School Psychology Review, 28: 395412.

Mc. Adoo, H.P., T. Luster and D. Perkins. 1993. "Family factors related to success among African- American adults: A secondary analysis of the Perry Preschool data." Paper presented at the Biennial meeting of the society for research in Child development. New Orleans.

Simon, B.S. 1999. "Family involvement in high school: Predictors and Effects." NASSP Bulletin, 86 (627): 8-19.

Topping, K. and S. Wolfendale. 1985. Parental Involvement in Children's Reading. Beckenham: Croom Helm.

Trusty, J. 1999. "Effects of eight-grade parental involvement on late adolescents' educational expectations." Journal of Research and Development in Education, 32(4): 224-233.

U.S. Department of Education 1994. Strong Families, Strong Schools: Building Community Partnership for Learning. Washington, D.C: Author.

Wolfendale, S. 1992. Empowering Parents and Educators. Working for Children. London: Cassell.

Wolfendale, S. (Ed.) 1989. Parental involvement: Developing Networks Between School, Home and Community. London: Cassell. 